https://doi.org/10.24297/jns.v6i0.7962

\title{
Cyclic Hominid Evolution in A Moroccan-Algerian Coastal Refuge: The Last Million Years
}

\author{
${ }^{1}$ Robert G. Johnson ${ }^{2}$ André Berger \\ ${ }^{1}$ Department of Earth Sciences, University of Minnesota Minneapolis, Minnesota 55455 \\ 2Earth and Life Institute, Université catholique de Louvain B-1348 Louvain-la-Neuve, Belgium \\ glenjay@bitstream.net, andre.berger@uclouvain.be
}

\begin{abstract}
To explain the abundance of species of genus Homo in the fossil record of Africa south of the Sahara, the small Moroccan-Algerian coastal zone that was isolated by the barren Sahara is proposed to have been a refuge in which cyclic evolution occurred. A dry climate in combination with a small population enabled natural selection to generate new sub species or species during each climate cycle. As generalized from the last two major glaciations, in each cycle three coastal zone climates of differing aridity occurred, depending on the latitudinal zonality of high latitude Gulf Stream flow. When initially isolated with minimal zonality (strong northward North Atlantic Drift of Gulf Stream water), the coastal climate was like today's, with warm summers and mild winter rains. Subsequently during intervals of ice sheet growth with intermediate zonality (weaker Drift), winters were colder, the climate was drier, and the environmental stresses increased. Finally, with the quite strong or complete zonality associated with Northern Hemisphere deglaciations (little or no Drift), extreme aridity often reduced the inhabitable area of the coastal zone. When each Eurasian deglaciation was completed, the isolation was probably briefly interrupted, as it was in the mid Holocene, by a well-watered savanna that developed across the Sahara. The savannas enabled each small and genetically modified population to increase and extend its range southward into the larger Africa. The pulses of evolution are directly related to glacial cycles by way of Earth's orbital eccentricity and precession of the equinox. The intervals of coastal zone isolation usually lasted almost 22,000 years, which is the time needed for the precession of the equinox to move summer around on Earth's orbit from one perihelion point to the next where monsoons are strong, and deglaciation and the savannas tend to occur. However, isolations as long as $\sim 76,000$ years also are found in the record because Eurasian ice sheet growth sometimes resumed before deglaciation was complete. In the last million years there may have been at least 18 pluvial savanna intervals when populations of new species or sub species of hominids would have extended their range by expanding on the savanna into the larger Africa or Eurasia. Periodic pulses of evolution of primitive hominids probably also occurred much earlier in the Pliocene with brief savannas but without large Northern glaciations. Generation of new species of hominids in the coastal zone and their injection into the larger Africa by savanna connections may therefore have been largely responsible for the abundance of genus Homo and predecessors in the fossil record and for our own Homo sapiens that we know today.
\end{abstract}

\section{Indexing terms/Keywords}

Hominid evolution, Ice age climate change, Orbital insolation, African monsoons, Hominid refugia, Human origins.

Academic Discipline and Sub-Discipline: Evolution, Hominid Evolution, Earth Science, Paleoclimate.

Subject Classification: Natural Science.

\section{[1] Method}




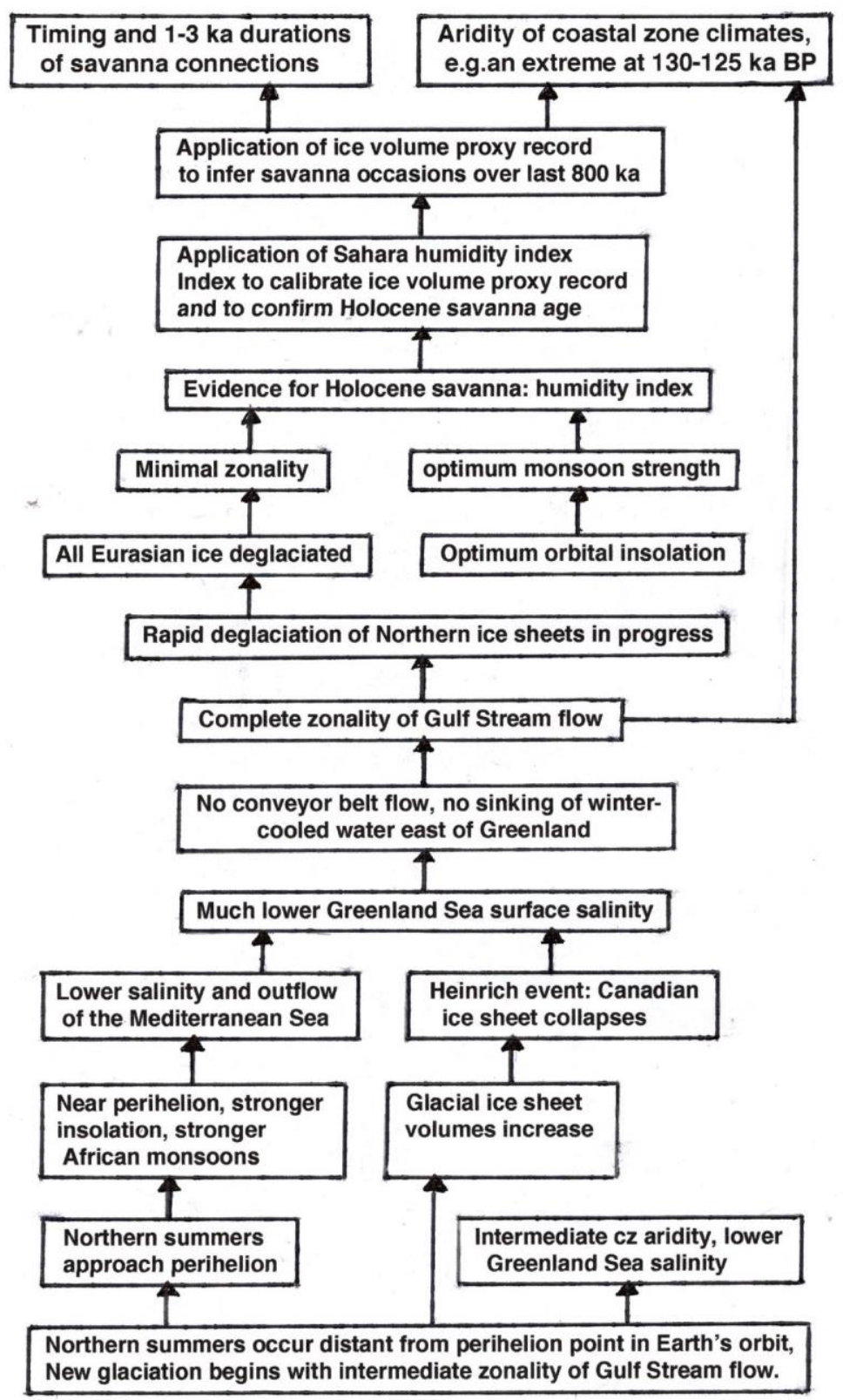

Figure 1 Block diagram of changing climate factors during the glacial climate cycle. The cause/effect linkages between these factors were analyzed to reveal new details of the glacial cycle and to discover the climates that selectively affected the coastal zone hominids.

The goal of this paper is to present a well-supported hypothesis of Hominid evolution in a refuge in the coastal zone of northwestern Africa. Two main secondary objectives are to explain how the complex system of climate factors depicted in the block diagram of Figure 1 caused the savannas that connected the isolated coastal zone (cz) to the larger Africa, and to evaluate the climate of the cz during the climate cycle. In performing the analyses to achieve these goals three tasks stand out: (1) the calculation of the Sahara temperature proxy for monsoon strength, (2) the use of temperature contrasts to obtain important storm paths, and (3) the use of modern analogs to obtain the aridity of coastal zone climates. The cause-effect relations indicated by the arrows in Figure 1 link together factors from many disciplines by means of published work or firm physical connections. To obtain the objectives, the fundamental relations between Earth's orbital variations and the African monsoons are first analyzed. The analysis continues with discussions of how monsoon variations bring about critical changes in the zonality of Gulf Stream flow by altering the strength of thermohaline circulation and conveyor belt flow. Finally, 
the last two major deglaciations are analyzed in terms of the Gulf Stream zonality changes and the resulting paths of storms and precipitation that determine glaciation or deglaciation. The analysis of known deglacial effects and events during the Holocene reveals the timing and duration of that savanna, which is a model for others. The deglaciation of the preceding glacial cycle reveals the extreme to which the coastal zone aridity can go. In some of these analyses, the results are needed in subsequent steps and therefore are presented as part of the body of the analysis.

\section{[2] Introduction}

As described in a review by deMenocal[1], a long fossil record of the hominid family over the last $4.2 \mathrm{Ma}$ (million years) of Plio-Pleistocene time is found in central and southern Africa, beginning about the time the Mediterranean sea became reconnected to the Atlantic by land subsidence at the Strait of Gibraltar[2]. This event isolated the adjacent Moroccan-Algerian coastal zone between the sea and the barren Sahara Desert. Substantial evidence of the evolution of the hominid family throughout the Plio-Pleistocene is found in the coastal zone north of the Sahara[3], but the fossil record is much more abundant in the larger Africa to the south. Consequently, the evolutionary process has been thought to have occurred south of the Sahara in the larger Africa, and step-like climate changes toward drier and more open environments have been proposed to have favored hominid evolution there[1,4]. However, no refugia that could have facilitated hominid evolution south of the Sahara have been identified, and puzzling questions remain unanswered.

Why did our hominid family in general and our genus Homo in particular evolve in Africa and not elsewhere? Various species of primates have occupied jungles and wooded plains in other parts of the world during Cenozoic time, yet it is on the wooded plains of Africa that we find extensive fossil evidence of the evolution of mankind's family over the last four million years. Although the main thrust of hominid evolution probably occurred in Africa, there is evidence that a few species did evolve in Eurasia, as discussed by Stewart and Stringer[5]. These species could have originated in Africa and later undergone additional evolution in Eurasia by means of refugia resulting from glacial ice sheet extensions and related climate changes. Such exceptions do not change the conclusion that Africa was the seat of hominid evolution.

Another puzzling question is: If hominids evolved in the fossil-rich regions of central and southern Africa, then why did the apes and chimpanzees that also lived there remain apes and chimps? The argument that regional environmental change south of the Sahara may have affected only hominids is not satisfying in the absence of specific hominid refugia in those regions. Moreover, the large hominid populations in the area to the south would not have experienced the climate extremes associated with cycles of glaciation in Northern Hemisphere higher latitudes. Strong environmental natural selection would have been lacking and local climate changes are not likely to have affected a widely distributed hominid population enough to have caused frequent speciation. This is consistent with a study of the mammal community at the Omo site in Ethiopia conducted by Bobe et al.[4], who reported that "climate forcing in the late Pliocene is more clearly indicated by population shifts than by marked turnover at the species level." This conclusion for the mammal community in general seems inconsistent with the variety of fossil species of genus Homo and more primitive members of the family of man south of the Sahara.

These pieces of the puzzle of hominid evolution all fall into place if much of the hominid evolution occurred in the small isolated Moroccan-Algerian refuge along the Atlantic and Mediterranean coasts (hereinafter called the Moroccan coastal zone) of northwestern Africa. The periodic reconnection of the coastal zone to the greater Africa by way of savannas generated by stronger monsoons is suggested by evidence from the recent Holocene and from the last interglacial[6,7,8,9]. In this small isolated region, enough annual precipitation now occurs (Fig. 2) to support an environment in which a small hominid population could have thrived. However, in past times during the Pleistocene glaciations, the coastal environment was usually more stressful than today, and an abiding principle of evolution is that small populations under selective stresses tend to evolve rapidly. In that regard, the last million years as discussed in this paper are of particular interest because a large increase in hominid brain size occurred after about $780 \mathrm{ka}$ BP[1] (ka = thousands of years), with much overlap in species brain size[10]. In 
recent years an increasing number of fossils of new hominid species have been reported from northwestern Africa, and a pan-African hominid origin has recently been suggested[11]. The present paper proposes instead that the significant hominid evolution occurred north of the Sahara., and was dominated by glacial climate cycles and the occasional connection of the Moroccan coastal zone to the south of Africa by a narrow range of stronger monsoons.

The principal objective of this paper is to argue the case for cyclic savanna connections across the Sahara into the larger Africa over the last million years of Pleistocene climates. It is the savanna connection that made the abundant hominid fossil record possible. The occurrence or non-occurrence of the savanna is critically dependent on changes in oceanic circulation and glacial ice sheets that are reflected in the world ocean oxygen isotope ratio proxy for changes in world sea level and glacial ice volume.

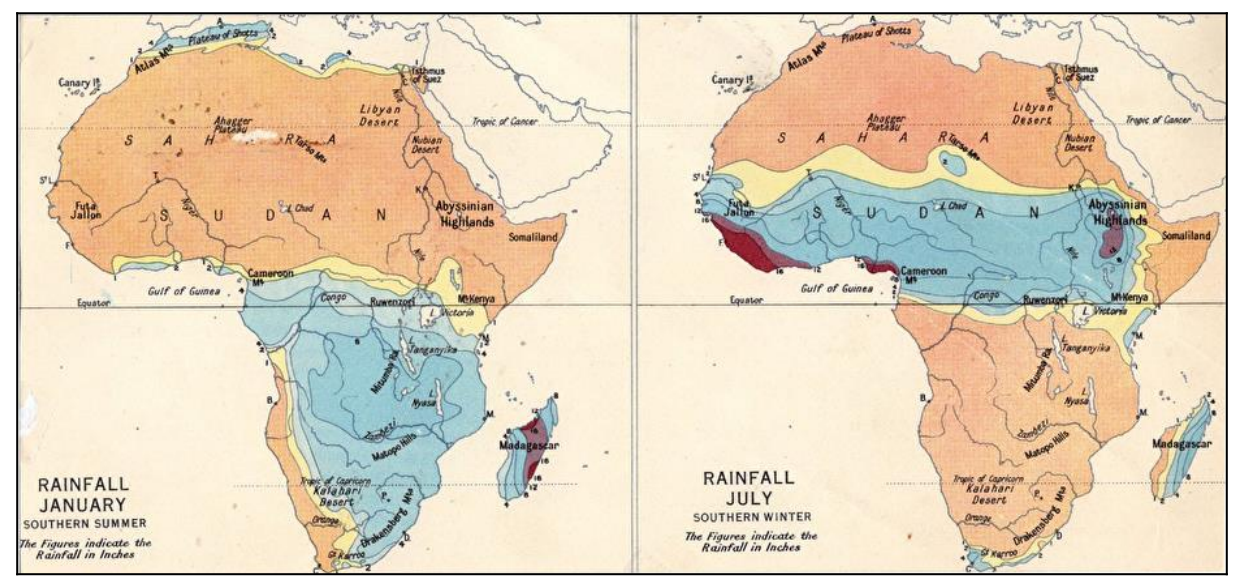

Figure 2 Rainfall in January and July in Africa [16]. January rains in the Moroccan-Algerian coastal zone range from less than 1 inch at the edge of the Sahara to more than 4 inches along the coast. Note the dry conditions along the southwest coast due to the cold Benguela Current.

The description of the oceanic changes focuses on those factors that decrease the so-called northward conveyor belt flow [12] of Gulf Stream water that shapes atmospheric flow patterns and can bring extreme aridity to the Moroccan coastal zone. Those oceanic factors include decreases of Mediterranean salinity and outflow rate caused by stronger monsoons, and the occurrence of Pleistocene ice age events that flood the high latitude North Atlantic with low-salinity water. As discussed in section 6.3, no other factor has placed more environmental stress on hominid populations in the Moroccan coastal zone than the decrease and occasional absence of the conveyor belt flow, with the resulting aridity of the coastal zone.

\subsection{Monsoons, orbital insolation, and Sahara summer temperatures.}

\subsection{The western African monsoons today}

An objective of this study is to show how past African monsoon variability relative to the present has contributed to the record of hominid evolution by interrupting periods of isolation in the coastal zone, and by interacting with the oceanic and atmospheric circulation to change the environment and the selective stresses on the resident hominids. Today, the July-August maximum of monsoon rain occurs in a latitude zone from the equator to $16^{\circ} \mathrm{N}$. The greater part of the precipitation comes from the ocean southwest of western Africa, carried by the West African monsoon. However, significant amounts of precipitation as far east as Ethiopia are probably drawn from southern land areas and the ocean east of Kenya (Fig. 2). In West Africa the monsoon season lasts only two to three months near $16^{\circ} \mathrm{N}$ but increases to about eight months at $8^{\circ} \mathrm{N}$. The moisture is carried over the land from the tropical ocean off to the southwest by southwesterly winds at lower altitudes of 1000 to $2000 \mathrm{~m}$ in response to rising air over the Sahara. The southwesterly winds alternate with the dry trade wind from the Sahara, 
known as the harmattan. Rainfall typically occurs when the dry trade wind air overlies the moist air. Longitudinal squall lines often form and move steadily westward with the trade wind flow[13]. In West Africa, the intertropical convergence zone marks the northern limit of precipitation.

Variation of summer insolation inputs to the Sahara is a strong factor that can increase monsoon strength by increasing Sahara temperatures. Changes of monsoon strength affect Northern deglaciations and the coastal

zone climate of the isolated hominids. Therefore, in this paper a simple model is used to convert orbitally calculated insolation changes at the Sahara latitude to temperature changes in the Sahara, which are a key to the climate cycle in the coastal zone.

\subsection{Insolation causing strong monsoons is linked to orbital variations}

The question of duration and numbers of isolation intervals over the last million years is of considerable interest for hominid evolution, as is the timing and duration of the savannas. To get answers to these questions it is necessary to consider the effects of orbital variations on African monsoons. It has been known for some time that the stronger monsoons, which brought rain to the arid Sahara, are correlated with occasions when Northern summers occurred near the perihelion point in Earth's orbit $[6,7,8]$. Those occasions are caused by the precession of the equinox, an effect that brings Northern summers around Earth's orbit to the perihelion point closest to the sun every $22 \mathrm{ka}$. Between different perihelion times of closest summer approach to the sun, however, substantial changes occur in the amount of solar insolation reaching the Sahara because the distance of the perihelion point from the sun varies continuously due to the gravitational attractions of other planets, which alter the eccentricity of the elliptical orbit. On the time scale of the last million years the eccentricity has varied from zero to as high as 0.052 with a present value of 0.0167 . At the higher values, summers occurred with earth closer to the sun, African monsoons were then much stronger, and discharge of the Nile River into the Mediterranean may have been two to three times larger than present $[6,9]$, excluding the modern effect of the Aswan high dam, of course.

Unless prevented by glacial climate cooling, a stronger Nile flow every 22 ka lowered the surface salinity of the Mediterranean Sea, reduced vertical circulation and oxygenation, and allowed dark sapropelic sediments to be deposited in the eastern Mediterranean. The lower salinity is climatically important because a large Nile flow and lower Mediterranean salinity can have cascading effects that favor deglaciation and can subject the hominids in the coastal zone to arid and highly stressful climates, as discussed in section 6 . Early in the glacial cycle, weak summer insolation in the Sahara causes weak monsoons, low Nile flow, and a more saline Mediterranean outflow, which can favor ice sheet growth[14]. To address the question of the number of isolation intervals in the last million years, an estimate of the monsoon strength at the perihelion points is useful. The nearly complete Northern deglaciations that allow savannas to develop across the Sahara are more likely to have occurred with slightly stronger monsoons shortly after the summer perihelion point. The monsoon strength is inferred from calculations of Sahara insolation. The first step was to list the ages of summer insolation maxima for the Sahara at $25^{\circ} \mathrm{N}$ from tabulations of calculated insolation supplied by Berger[15]. The next step was to convert the maxima of insolation to temperature differences above present to facilitate discussion of monsoon strengths and related oceanic circulation changes. The calculated Sahara temperature differences relative to today, are proxy for differences in monsoon strength.

\subsection{Conversion of orbital insolation to Sahara summer temperatures}

The past increases of summer temperatures on the Sahara relative to today are obtained from calculated insolation increases and the modern observed July-January seasonal temperature differences in the Sahara. The justification for the use of the temperature increase as a proxy for increase of monsoon strength is as follows. The West African monsoon is driven by large-scale differences between higher summer atmospheric temperature and lower atmospheric density and pressure over the Sahara on one hand, and on the other hand, lower temperature and resulting higher density and pressure over the dominant ocean area near the equator to the southwest of northern Africa. The oceanic surface temperatures are much less affected by seasonal insolation 
changes than the Sahara because the thick mixed oceanic surface layer has a large heat capacity and large thermal inertia. The dominance of the seasonal temperature change on the Sahara is illustrated in the Bartholomew Atlas[16], which gives a seasonal change of about $28^{\circ} \mathrm{F}$ at $25^{\circ} \mathrm{N}$, with oceanic temperatures from about $77^{\circ} \mathrm{F}$ to $80^{\circ} \mathrm{F}$ that are almost unchanged seasonally southwest of Liberia near the equator. This paper is concerned with summer temperature changes over the last million years, during which any small oceanic seasonal temperature change will be neglected and only that of the Sahara will be considered. Consequently, the times of maximum insolation and temperature on the Sahara near perihelion are also the times of maximum pressure differences that drive the monsoons. The maxima of orbital caloric summer averages of insolation on the Sahara at $25^{\circ} \mathrm{N}$ [15] are therefore used to identify ages of temperature maxima in the Sahara. Caloric halfyear averages of Sahara insolation differences relative to present are used to estimate the summer temperature increases in the Sahara relative to the present.

The caloric summer half of the year in each hemisphere is defined as the number of days in that half-year in which no summer day has less insolation than any winter day. The varying amounts of insolation have been calculated at thousand-year intervals for latitudes that are $5^{\circ}$ apart $[15,17]$. The tabulated average values of insolation supplied by A. Berger are expressed in units of langley's per day (ly/day) in which one ly equals 41840 $\mathrm{j} / \mathrm{m}^{2}$. The tables of computed caloric half-year averages are differences between past values of insolation and today's 1950 AD values in units of average ly/day. The past insolation values were derived from calculated orbital elements that include the effects of gravitational perturbations on Earth's parameters by other planets. The calculations by Berger[15] include perturbations by Jupiter and Saturn and are therefore slightly more accurate than earlier values calculated by Vernekar[17].

Using the assumption that oceanic temperatures in the past did not change significantly at the equatorial source of monsoon atmospheric flow, the past differences of Sahara summer temperatures above present at perihelion are alone a proxy for increases in monsoon strength. To derive the temperature proxy values from the Berger insolation tables, the number of ly/day per ${ }^{\circ} \mathrm{F}$ rise of Sahara temperature are needed. One measure of this rate is today's summer-winter caloric insolation difference at a point within the Sahara divided by the observed seasonal temperature change at that point. The additional insolation near perihelion is then divided by this rate to obtain the increase in the summer temperature proxy for monsoon strength. However, the seasonal differences in temperatures of the Sahara do not have a high precision. Therefore, the rates were calculated at longitude $20^{\circ} \mathrm{E}$ for latitudes $15^{\circ} \mathrm{N}, 20^{\circ} \mathrm{N}, 25^{\circ} \mathrm{N}$, and $30^{\circ} \mathrm{N}$, and their average rate of 9.6 ly/day per ${ }^{\circ} \mathrm{F}$ was used to convert the difference of summer insolation at $25^{\circ} \mathrm{N}$ relative to today into temperature increases near perihelion.

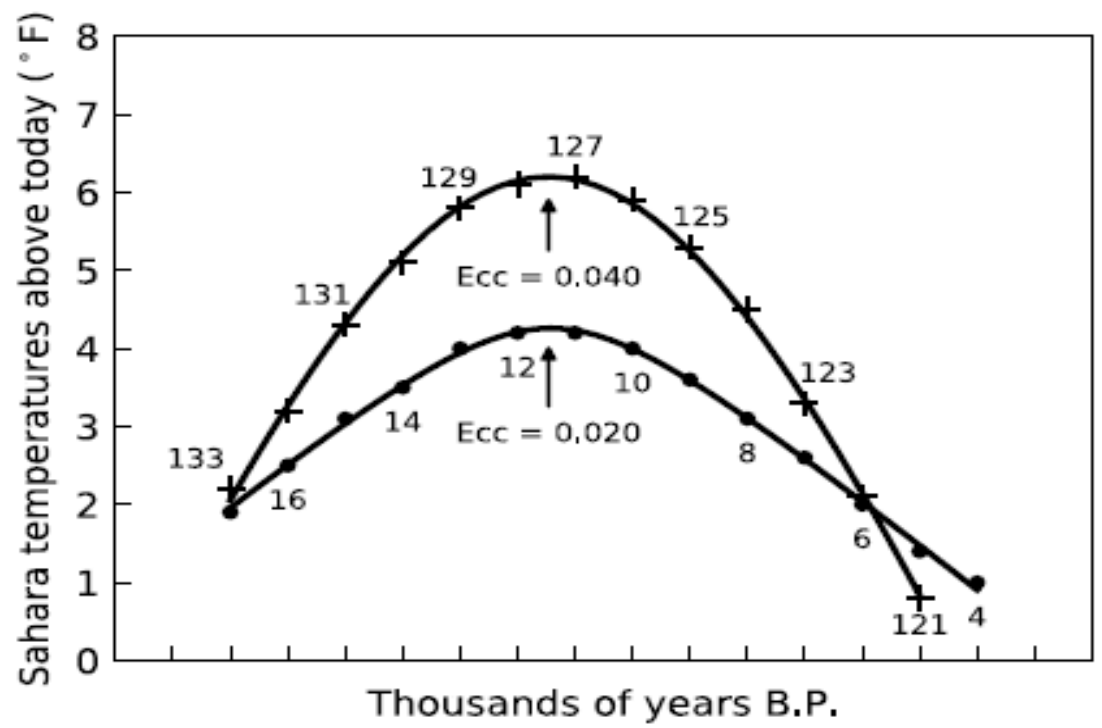

Figure 3 The increase and decline of the Sahara summer temperature differences above present as the precession of the equinoxes moves Northern summer around in Earth's orbit and through the perihelion 


\section{point during two recent cycles when savannas on the Sahara are known to have occurred. The changing Sahara temperatures are related in a complex way to the climate in the coastal zone.}

\subsection{Climate change in the coastal zone: aridity, Gulf Stream zonality}

Although there is strong evidence that savannas in the Sahara occurred in the last two glacial cycles, the savanna timing has remained uncertain. To obtain the timing and duration of these two savannas and to use this information to get the probable presence or absence of other earlier savannas it is necessary to consider the oceanic and atmospheric circulation that has governed the variations of coastal zone climate during Pleistocene glacial cycles.

As Ruddiman et al. noted[18, 19], Northern Hemisphere glaciation or deglaciation depends on where the storms go. But where the storms go depends on where the Gulf Stream water goes. This idea will be discussed here in terms of the zonality of Gulf Stream flow. That is: the extent to which the Gulf Stream flow continues eastward across the mid North Atlantic without having much of its water diverted into the northward flow of the North Atlantic Drift. This concept is useful because the amount of Gulf Stream zonality determines the aridity of the coastal zone, whether glacial growth or deglaciation occurs, and whether the speed of deglaciation is fast or slow.

The zonality depends on the sea surface salinity east and northeast of Greenland where the more saline surface water is winter-cooled, sinks, and drives the conveyor belt flow. That salinity is derived from the warmer and more saline Gulf Stream water of the conveyor belt flow that is usually dominant, because its salinity is significantly increased by saline Mediterranean outflow water. However, the conveyor belt flow can be decreased during times of strong monsoons that diminish the Mediterranean outflow. Likewise, at times of Heinrich events, that salinity is greatly decreased by low-salinity water derived from the Canadian ice sheet by way of the Northern gyre. These two factors can have profound effects on the environment of the isolated hominids.

\subsection{Climate and circulation effects of Heinrich events}

\subsection{Origin of Heinrich events}

Heinrich and Heinrich-like events reduce the rate of conveyor belt flow by making it less saline. Heinrich events are roughly cyclical during glaciations but cannot be precisely predicted. The climate effects depend on where in the glacial cycle they and stronger monsoons occur. Heinrich events[20]usually originate in Canada when a glacial ice dam, formed by an ice stream that is fed by heavy precipitation in the Labrador-Quebec area, flows northward through Ungava Bay and across Hudson Strait[21]. The repeated occurrence of the Hudson Strait ice dam over the last million years or more is consistent with the two York Canyon spillways that drained meltwater from the impounded ice accumulation west of the cross-flow. The canyons extend $75 \mathrm{~km}$ across the Meta Incognita Peninsula of Baffin Island from Hudson Strait to Frobisher Bay. These spillways have been eroded into the hard crystalline bedrock to depths greater than $500 \mathrm{~m}$ at the Frobisher Bay end, as described by Blake(22). When this ice stream is overwhelmed by the build-up of thousands of years of glacial accumulation on the ice dome over Hudson Bay to the west [23], the ice from the Hudson Bay area pours out through Hudson Strait. The resulting disintegration of the ice dome can last for 2 ka or more. During Heinrich events, the resulting less saline water of the Northern gyre can mix into the northward-flowing conveyor belt current and can stop all or nearly all northward flow of mid ocean Gulf Stream water. The gyre water salinity and temperature variations reflect the irregular cyclic Heinrich events that are inferred from the deep-sea sediments[20] and the Greenland GRIP ice core record of oxygen isotope ratio variation[24]. The strength of Heinrich events and Heinrich-like events can vary widely, and they have initiated glaciations and deglaciations, depending on when they occur in the Northern Hemisphere glacial cycle. The rule is not rigid, but it appears that if a Heinrich event occurs early in the long glacial cycle it can cause a net acceleration of ice sheet growth. If it occurs late in the cycle it will tend to initiate or accelerate deglaciation by moving the zonality close to the complete state where Northern ice sheets are starved for precipitation. In either case there is probably an extremely arid environment for hominids in much of 
the isolated Moroccan coastal zone. Here, two quite different examples from the Wisconsinan Glaciation are described. The well-studied event, $\mathrm{H} 1$, is described in section 7 .

\subsection{The first Heinrich-like event in the Wisconsinan Glaciation}

The first such ice dam of the recent Wisconsinan Glaciation was overwhelmed about $116 \mathrm{ka} B \mathrm{P}$, an age measured in a large coral cobble from a brief sea stand on uplifted Barbados at the University of the West Indies site[25], and in negative pulses indicating a brief sea rise in the marine isotope ratio record[26]. The event and sea stand occurred after a world sea level fall of $12 \mathrm{~m}$ from the last interglacial level. The ice dam had impounded giant fresh-water Lake Zissaga over the Hudson Bay region[23], and its rapid release together with buoyant deglacial effects raised world sea level by $3.8 \mathrm{~m}$. The duration of the zonal Gulf Stream flow at $116 \mathrm{ka}$ BP is not known, but the event ended the temperate climate tree pollen in the record of the last interglacial in Western Europe[27] and apparently started the last Eurasian glaciation by reducing the interglacial conveyor belt flow to a point favorable for ice sheet growth.

\subsection{Heinrich event $\mathrm{H} 5$ as seen in the Greenland GRIP ice core record}

The GRIP record before and after Heinrich event $\mathrm{H} 5$ is illustrated in the example of Figure 4 . The $\mathrm{H} 5$ cycle began shortly before $50 \mathrm{ka} \mathrm{BP}$ during the mid Wisconsinan glaciation with a stable Sahara temperature about $1^{\circ} \mathrm{F}$ above today, and a cold Northern gyre. The conveyor belt flow was probably absent for more than a thousand years during $\mathrm{H} 5$, with a nearly complete zonality of the Gulf Stream flow caused by the flood of icebergs and cold meltwater discharged through Hudson Strait into the Labrador Sea and Northern gyre. The flood would have started when the accumulation of glacial ice over the Hudson Bay region increased and overpowered the dam formed by ice stream flow across Hudson Strait[23]. When the flood of ice ended, the temperature and salinity of the Northern gyre rose. Many storm paths moved northward to follow the contrast line between warmer ocean and cold ice-covered Greenland coast, bringing warmer snowfall with less negative isotope ratios to the GRIP ice core site. Over the next $5 \mathrm{ka}$ with the glacial dam across Hudson Strait restored by ice stream flow, the southward extension and the surface elevation of the accumulating ice over the central Canadian region slowly increased. The average path of storms consequently moved southward, Greenland snowfall became colder. At 44 ka BP the Hudson Strait cross flow was again overpowered by accumulated ice flowing from the west, and the next Heinrich event began with zonal Gulf Stream flow. The examples of Figure 4 fall within a wide range of durations of such events, some of which originated due to less frequent outbursts of 


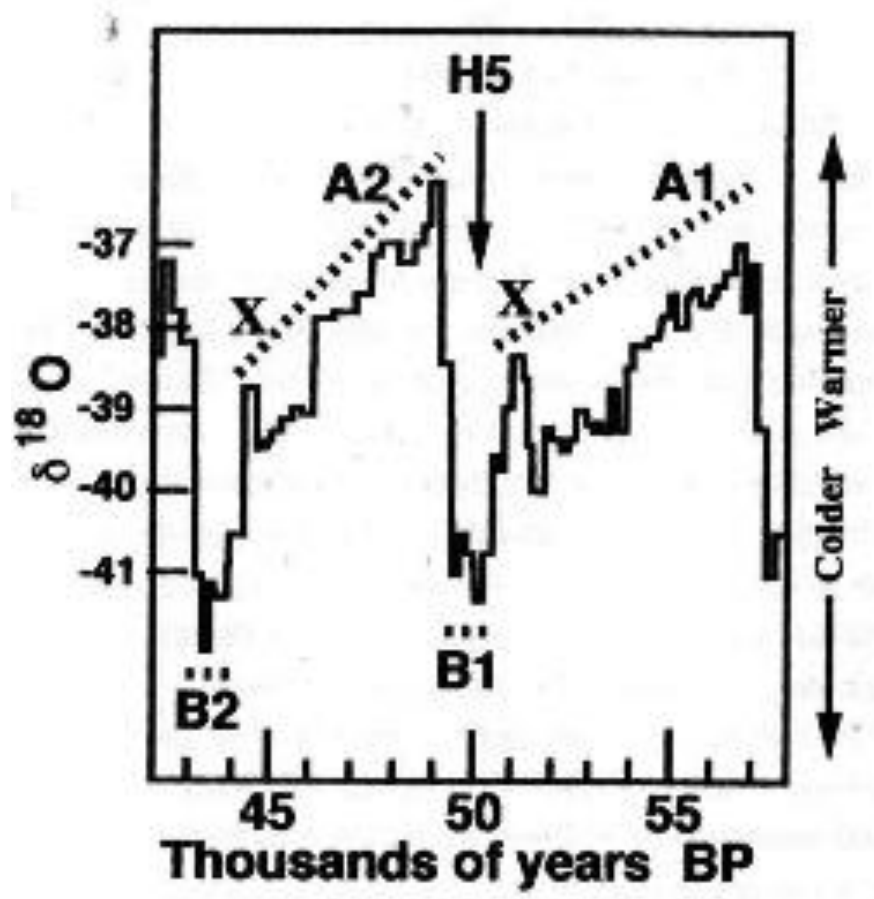

Figure 4 Greenland GRIP ice core record of the oxygen isotope ratio in a time frame around Heinrich even $H 5$ [24]. The record is interpreted as a proxy for storm path variations caused by the repeated collapse and restoration of the central Laurentide ice mass in Canada. B1 and B2: Laurentide Ice sheet collapse, A1 and A2: maximum temperature of the Northern gyre, $X$ : diminishing ice flow across Hudson Strait. See text.

glacial ice from the Baltic Sea region. But Hudson Strait ice dams would have occurred often throughout the Pleistocene, and no significant deglaciation may have occurred without an ice dam failure as part of the process that established a deglaciation with a strongly zonal flow of the Gulf Stream and an interval of extreme aridity for the coastal zone hominids.

\subsection{African monsoons, Mediterranean outflow, and conveyor belt flow}

West African monsoon variations make major contributions to the zonality variations by way of greater Nile flow and resulting lesser salinity of the Mediterranean Sea. Even the somewhat weaker monsoons significantly reduce the salinity of the Mediterranean. In the last $250 \mathrm{ka}$, ten out of eleven perihelion points have been accompanied by dark sapropelic sediments deposited in the eastern Mediterranean Sea as a result of greater amounts of nutrients and fresh water stratification from stronger Nile River flows driven by monsoons[7, 28]. The salinity in the upper levels of the entire Mediterranean has been decreased by the greater Nile flow[29] as an indirect response to monsoons near the perihelion point.

The link between the reduction of Mediterranean salinity and the increase in zonality of Gulf Stream flow is the Mediterranean outflow. Today the outflow, with its $\sim 2.8 \mathrm{ppm}$ (parts per thousand) greater than North Atlantic salinity today at Gibraltar, is driven by the density difference between the Mediterranean and the North Atlantic water[30]. After leaving Gibraltar the outflow sinks and mixes into Atlantic water. The mixture reaches a buoyant equilibrium at $\sim 1500 \mathrm{~m}$ depth. Due to geostrophic effects some of the mixture then rises and mixes into the North Atlantic Drift water[31] between longitudes $19^{\circ} \mathrm{W}$ and $14^{\circ} \mathrm{W}$. The density gradients caused by this saline addition increase the flow velocity beneath the surface at $54.5^{\circ} \mathrm{N}$, as depicted in the Greatbatch and Xu flow field[32] of Figure 5. The flow between $19^{\circ} \mathrm{W}$ and $14^{\circ} \mathrm{W}$ feeds into the Norwegian Current that supplies the conveyor belt water that sinks northeast of Greenland[12]. Therefore, the strengthening of African monsoons when approaching perihelion reduces the conveyor belt flow to below the already smaller flow of glacial times, and brings the Gulf Stream flow closer to complete zonality. 


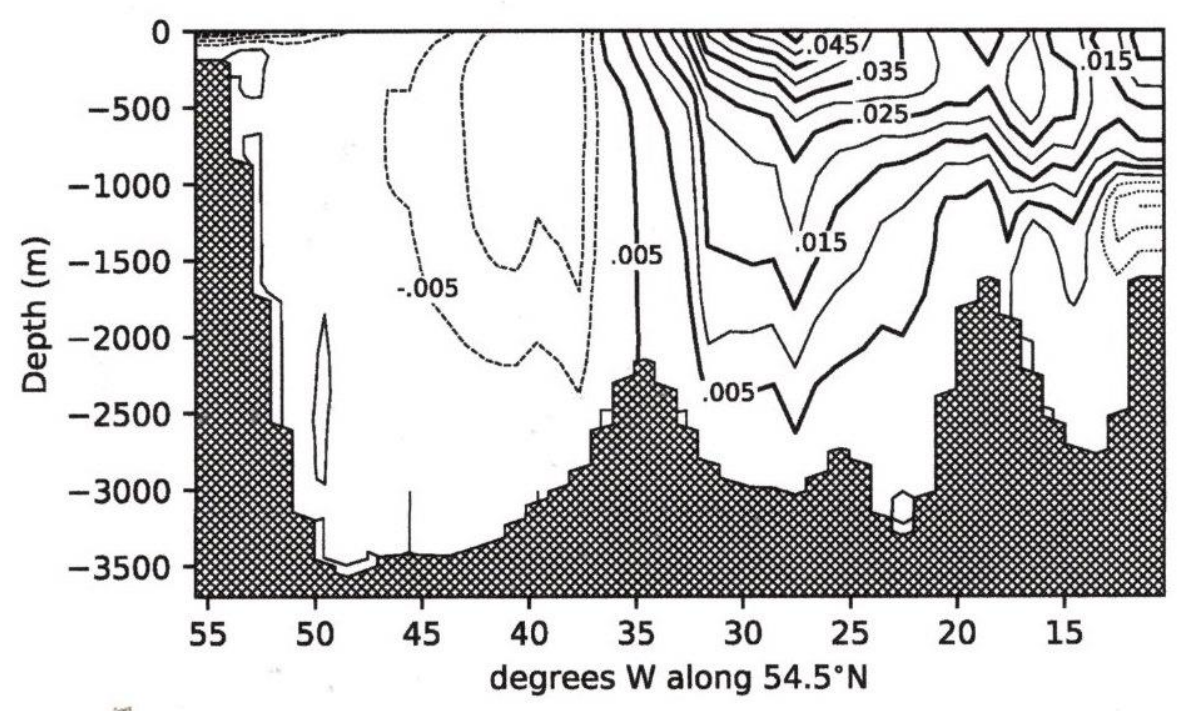

Figure 5 Northward components of flow in the North Atlantic at $54.5 \mathrm{~N}$, slightly modified from Greatbatch and $\mathrm{Xu}$ [32]. Velocities in $\mathrm{m} / \mathrm{sec}$ were derived from densities calculated from temperature and salinity measurements. The pattern of higher sub surface velocities between longitudes $14 \mathrm{~W}$ and $19 \mathrm{~W}$ is attributed to the saltier admixture of Mediterranean outflow water that makes a major contribution to the winter-cooled sinking that now drives the conveyor belt thermohaline flow. Dotted lines are southward flows. Data covers the years from 1970 to 1974.

The climate extremes in the Moroccan coastal zone that resulted from different amounts of zonality ranged from the benign interglacial climate of today with minimal zonality and strong northward conveyor belt flow to waterless aridity in parts of the coastal zone late in the glacial cycle with complete Gulf Stream zonality. To see how the aridity occurred, it is necessary to consider the dynamics of storm movement in Northern higher latitudes. North of the trade wind zone, storms move eastward beneath atmospheric jet streams on paths perpendicular to land or ocean temperature gradients. The sharper the gradient the tighter is the path of the storm controlled. This means that storms have often followed the edges of cold ice sheets or lines between sharply contrasting areas of oceanic temperatures. If storms drag moist air from a warmer ocean over cold ice sheets, glacial growth will occur[18]. If they drag warmer dry air over ice sheets, deglaciation occurs.

\subsection{Different Gulf Stream zonalities and the coastal zone climate.}

\subsection{Minimal zonality: a benign interglacial coastal zone climate.}

The benign interglacial coastal zone climate of today is attributable to the fact that much of the mid Atlantic Gulf Stream water turns northward toward the higher latitudes in the slow flow of the North Atlantic Drift (Fig. 6), the northeastern part of which becomes the Norwegian Current. The total northward volume flow rate is estimated to be $13 \times 10^{6} \mathrm{~m}^{3} / \mathrm{sec}$ [33]. The Drift is a major part of North Atlantic thermohaline circulation described by Broecker as the "conveyor belt flow"[12]. The rate of conveyor belt flow depends on the winter-cooled sinking of more saline surface water northeast of Greenland, which the northward flow replaces, and on the amplification of the replacement flow by storm wind stresses. Relatively little Gulf Stream water continues eastward to the vicinity of Spain, and the southward part of the return flow in the form of the Canaries Current is now weak. Because that return flow is weak, the sea west of the Moroccan coastal zone remains warmer than during glacial times, and when the latitudinal sea surface temperature gradients increase in winter, storms bring welcome rains to the Moroccan coastal zone. 


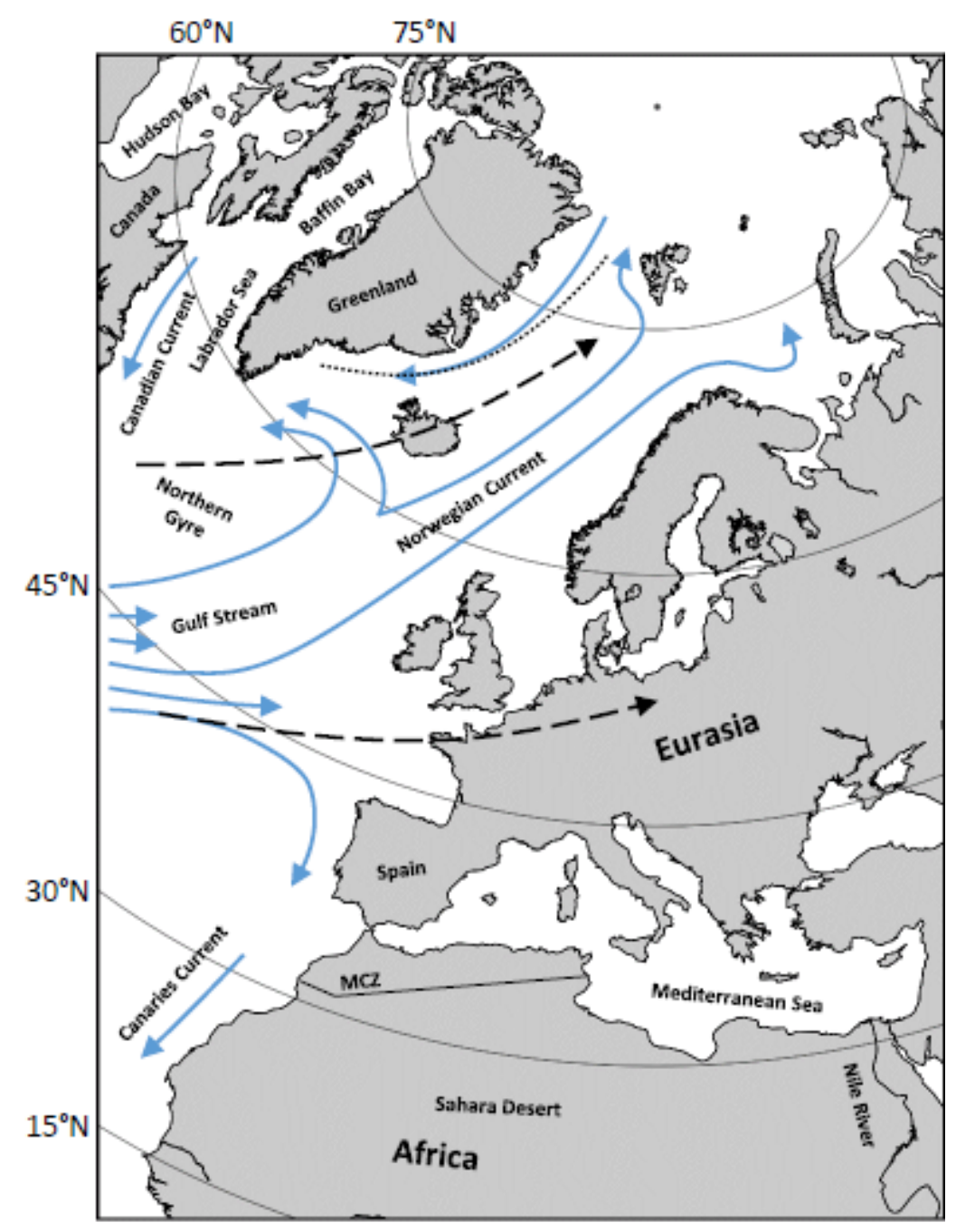

Figure 6 Minimal zonality. Today's oceanic circulation and idealized storm paths in the northeastern North Atlantic and western Eurasia. Black dotted line is the oceanic polar front, now just east of Greenland. Dashed black lines are principal storm paths that tend to follow lines of temperature contrast. Blue lines are oceanic flows. Note the weak and warm Canaries Current.

\subsection{Intermediate zonality: a southern California climate}

During the long intervals of Northern continental ice sheet growth, the conveyor belt flow was reduced below present by varying amounts that increased the zonality of the Gulf Stream flow relative to today, as in the example of the stronger Canaries return flow as suggested in the maps of Figures 7 and 8. The reduced winter-cooled sinking of Drift water probably occurred to the south of northern Greenland. With colder and often ice-covered seas west of Scotland and Scandinavia, the line of strong temperature contrast parallel to the eastern Greenland coast was lost. Relatively weak latitudinal gradients of sea surface temperature then steered storms eastward and ensured the Eurasian ice sheet growth. Storm paths at these latitudes likewise ensured Canadian ice sheet growth when monsoons were weak. With an intermediate amount of zonality, the southward Canaries Current return flow would have been strengthened. The return flow would have been cooled by the higher latitude glaciation, and the adjacent land climate of northwestern Africa may have been similar to that adjacent to the California Current of today. That current carries cooler water southward along the southern California and Baja California coasts. A relatively dry climate results, but with varying amounts of winter rains. The hominids living in the small coastal zone would have experienced a Southern California or Baja California climate, but life would not have been as easy as during interglacial periods like today. 


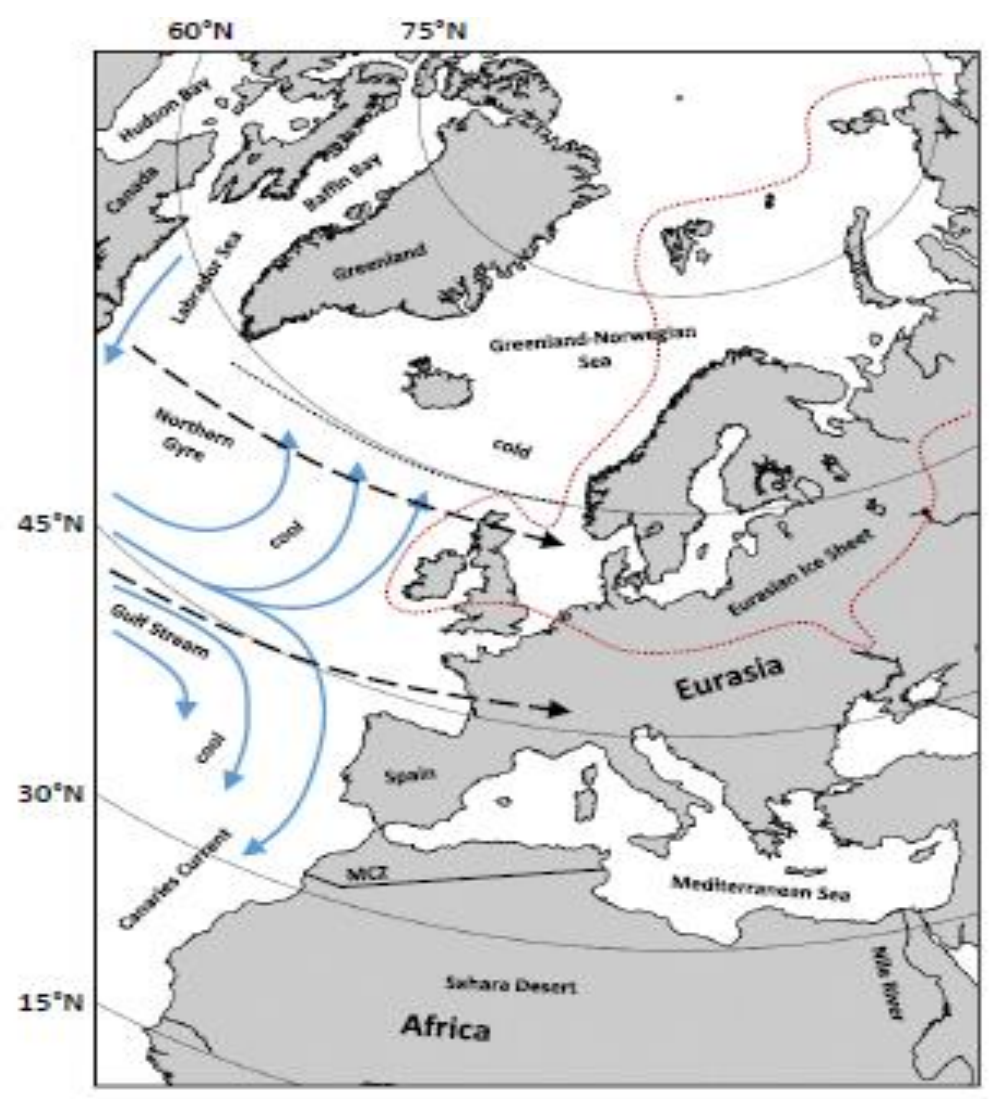

Figure 7 Intermediate zonality. Oceanic circulation and idealized storm paths in the northeastern North Atlantic and western Eurasia during a time of maximum growth of one of the large Eurasian ice sheets over the last million years. Weaker conveyor belt thermohaline circulation probably held the polar front (dotted line) at about $60^{\circ} \mathrm{N}$. Southward return flow of the Gulf Stream was somewhat stronger than today. In the coastal zone, winters would have been colder and summers dryer than today. Storm paths: heavy dashed lines. Oceanic flows: blue lines. Red dotted line: maximum extent of the Saalian Glaciation in Eurasia[34].

\subsection{Complete Gulf Stream zonality: a Namib and Kalahari Desert climate}

Complete zonality of Gulf Stream flow occurred during glacial termination 2, the transition between stage 6 in the marine isotope ratio record of ice volume and the last interglacial stage $5 \mathrm{e}$. This transition is marked by the combined effects of a strong Heinrich event and strong monsoons. The termination is centered in the marine sediment record at $128 \mathrm{ka}$ BP. The complete zonality implies an extreme aridity in the coastal zone. The very strong return flow of the Gulf Stream as the cold Canaries Current in Figure 8 would have had an accurate analog in today's Benguela Current, which flows northward along the coast of southwest Africa, and consists of cold Antarctic water[16]. Its climate effects are more extreme than those of the California Current. The cold Benguela Current is responsible for the waterless desert strip along the Namib coast from latitude $15^{\circ} \mathrm{S}$ to $30^{\circ} \mathrm{S}$ and for the adjacent Kalahari Desert. However, the aridity becomes less severe eastward where the Kalahari ends up to 1100 $\mathrm{km}$ from the coast. In the Moroccan coastal zone, the analogous cold mixed Gulf Stream return flow would probably have made the African coast from Gibraltar at $36^{\circ} \mathrm{N}$ southwestward to $20^{\circ} \mathrm{N}$ likewise waterless, with arid desert conditions as far as $1000 \mathrm{~km}$ to the east. Just as in southern Africa today east of the Kalahari, an area of the Algerian coast on the Mediterranean, 1000-1500 km east from Gibraltar, would have been less affected and probably remained inhabitable with some winter rains. But while the Gulf Stream flow remained completely zonal during the Eurasian deglaciation of termination 2, the total inhabitable area of the coastal zone would have been much smaller, and the small population of coastal zone hominids along the Mediterranean to the east would have struggled to survive in an arid or semi-arid environment. A similar struggle may 


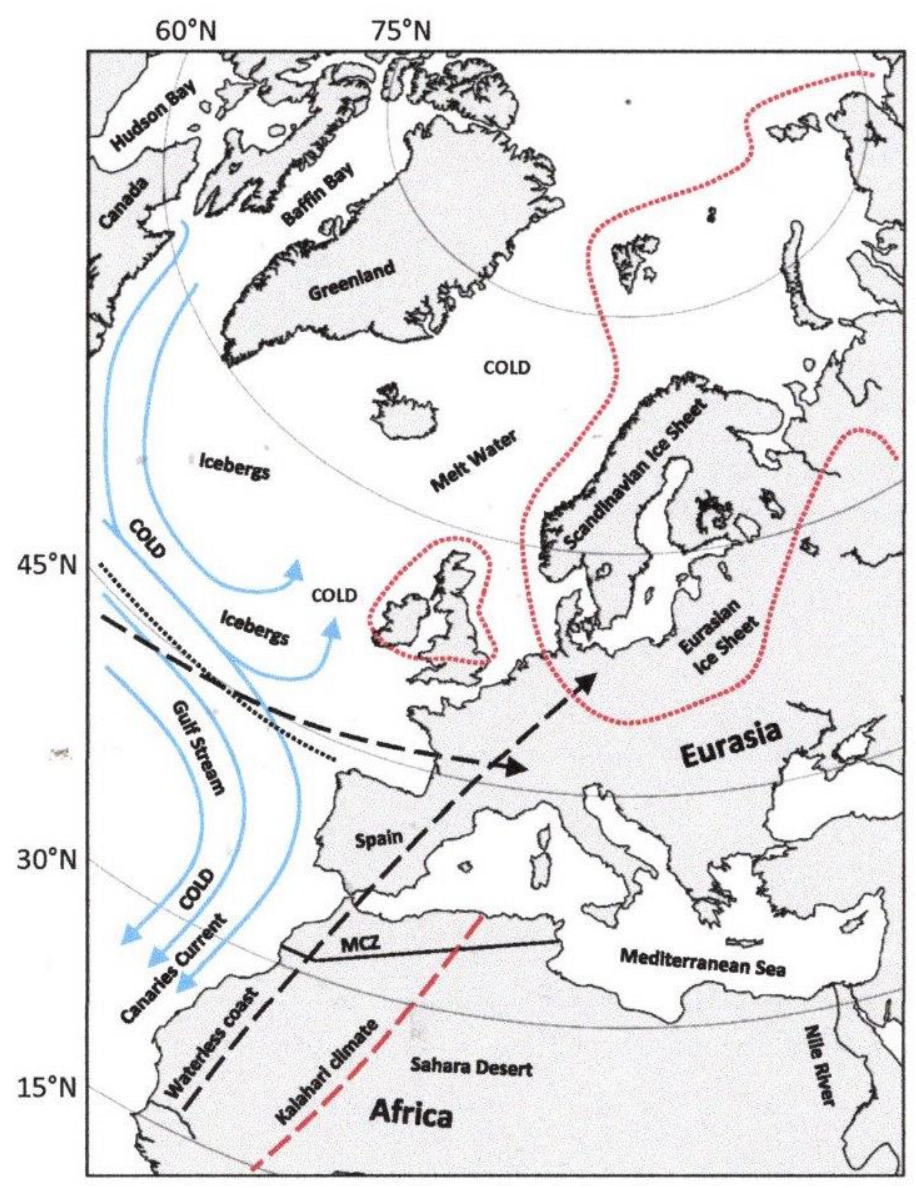

Figure 8 Complete zonality. Oceanic circulation and idealized storm paths, black dashes, in the northeastern North Atlantic and western Eurasia soon after the beginning of termination 2. Red dots mark the maximum extent of the last substage of the Saalian glaciation, the Warthe[34]. The conveyor belt flow was eliminated by reduced salinity and volume of the Mediterranean outflow and the discharge of ice and meltwater into the northern North Atlantic from the collapsing Laurentide ice sheet[20, 23]. The cold Northern Gyre extended all the way across the North Atlantic to Ireland making the Gulf Stream flow completely zonal. Red dashes mark the eastern edge of the barren desert analog of the Kalahari. Most winter storm paths would have been zonal at about $45^{\circ} \mathrm{N}$. Summer storm paths were meridional, carrying warm air to the Eurasian ice sheet, see text.

have occurred at many other times in the last three million years. But such struggles ended when the Eurasian deglaciation was completed, the conveyor belt thermohaline circulation was restored, and a benign coastal zone climate returned.

\subsection{Monsoons and Heinrich events in the last two major deglaciations}

\subsection{Two greatly different glacial-interglacial transitions}

The last two major deglacial events in the marine records, termination 2 ending glacial stage 6 about 125 ka BP, and termination 1 ending glacial stage 2 slightly before $6 \mathrm{ka}$ BP, suggest the conditions that made the connecting savannas possible. As discussed in Section 8 , it appears that savannas could only develop in a narrow window of time after the Eurasian deglaciation was completed and before an interglacial or interstadial began. These two deglaciations are significantly different in many ways, but both had intervals when strong zonality would have made the coastal hominids' lives quite difficult. However, the first part of the stage 6 deglaciation is anomalous and is invisible in the proxy record for ice volume and world sea level. 


\subsection{The anomalous deglaciation of the Drenthe substage}

In a broad sense, the deglaciation of glacial stage 6 in the marine oxygen isotope ratio record began before 140 ka BP with world sea level probably below -120 m and after all the Siberian Rivers entering the polar ocean, except for the Lena, had become blocked by flow of glacial ice. This sequence of events is described by Arkhipov et al.[34] as the Drenthe substage followed by the Warthe substage of the great Eurasian deglaciation, known as part of the European Saalian glaciation. The Drenthe deglaciation began with the overflow of a giant Siberian lake formed by the ice-blocked Siberian rivers. The abrupt erosive overflow of fresh water through the Turgai pass cascaded through the Aral, the Caspian, and the Black Seas and then through the Bosporus Strait into the Mediterranean. The initial pulse of melt water would have lowered the Mediterranean Sea surface salinity and consequently would have reduced or eliminated the saline outflow at Gibraltar. The resulting loss of conveyor belt flow and the increase of Gulf Stream zonality initiated the Drenthe deglaciation, which continued to supply feedback melt water to the Mediterranean, maintaining the Northern Hemisphere deglaciations until loss of Siberian ice opened at least one river channel and drained the giant lake. The Drenthe deglaciation resulted in a brief world high sea level of about $+4 \mathrm{~m}$ at $136.5 \mathrm{ka} B P$, as measured by a survey of differentially uplifted wave cuts that were made at that time on now uplifted Barbados [35]. However, this high sea level and the deglaciation leading to it are invisible in the marine isotope ratio proxy records.

The invisibility of the Drenthe deglaciation in the oxygen isotope proxy record can be explained by the sea icefree open polar ocean that developed when the Siberian Rivers became blocked. Evaporative fractionation then concentrated heavier $\mathrm{H}_{2}{ }^{18} \mathrm{O}$ in the effectively isolated deep polar ocean. This depleted the $\mathrm{H}_{2}{ }^{18} \mathrm{O}$ in the world ocean, making the world ocean isotope ratios of that time too negative and thus masking the deglaciation in the usually reliable oxygen isotope ratio proxy record. The $+4 \mathrm{~m}$ high sea level implies a significant loss of Antarctic glacial ice also. The brevity of the $+4 \mathrm{~m}$ high sea stand at $136.5 \mathrm{ka}$ BP is indicated by the absence of any thick coral reef growth near the wave cuts made at the $+4 \mathrm{~m}$ level at that time on now uplifted Barbados. This suggests that ice sheet growth was renewed and the river channels were again closed by ice flow soon after the giant Siberian lake broke through the partly deglaciated ice sheet and was drained into the polar ocean. This ended the melt water overflow into the Mediterranean Sea at a time when Earth was in a distant part of its orbit from the perihelion and weak zonality favored the ice sheet re-growth.

\subsection{The deglaciation of the Warthe substage: termination 2 in the marine record}

After $6.5 \mathrm{ka}$ of re-growth, summers were occurring nearer to the perihelion point, and world sea level had fallen to $-80 \mathrm{~m}$. A large Heinrich event then occurred in combination with quite strong monsoons that reduced the Mediterranean outflow at Gibraltar. These two factors, aided by melt water feedback, caused the loss of all conveyor belt flow and the complete zonality of Gulf Stream flow, which caused an arid climate for the Moroccan coast, and great hardship for the coastal hominids. However, it was followed by the last interglacial beginning at $125 \mathrm{ka}$ BP during which Sahara temperatures declined as in Figure 3, passing through the narrow window of time during which a connecting savanna could develop around $122 \mathrm{ka}$ BP. The total span of time needed for this complex transition from $\sim 140$ to $125 \mathrm{ka} B P$ is about the same as for termination 1, which had no major interruptions, see Fairbanks, Figure 2 in reference [36].

\subsection{Termination 2: complete zonality and a rapid deglaciation}

During termination 2 in the marine records only about $5 \mathrm{ka}$ or less were required to deglaciate world ice volumes from a proxy sea level of $-80 \mathrm{~m}$ at $130 \mathrm{ka}$ BP, as measured on uplifted coral reefs in New Guinea[37], to a level 6 $\mathrm{m}$ above present at $125 \mathrm{ka}$ BP [38, 39]. The increase from intermediate zonality during glacial growth to complete zonality during deglaciation would have greatly increased the environmental stresses on the isolated hominids. Therefore, it is important to see how the complete zonality of termination 2 was obtained, and why it could have been a characteristic of other Pleistocene deglaciations when orbital eccentricity was larger than today and summers at perihelion also occurred closer to the sun. 
The conventional termination 2 deglaciation ended the Warthe substage of the Saalian glaciation in Eurasia, when an ice sheet had extended over the British Isles, Scandinavia, northern and eastern Europe, and much of Siberia[34]. The New Guinea starting date of $130 \mathrm{ka}$ BP for the deglaciation is the same as another starting event in a deep-sea sediment record from the Mediterranean. At $130 \mathrm{ka} \mathrm{BP}$, increasingly large Nile River discharges caused salt water foraminifera to disappear from the sea surface in the eastern Mediterranean at the site of deepsea core TR127[40]. This effect occurred at the base of the sharp negative rise in the isotope ratio proxy record of termination 2. It is not just a coincidence that the $130 \mathrm{ka} \mathrm{BP}$ age of the cessation of ice sheet growth found in New Guinea coral reefs[37] and the age of larger Nile flow causing reduced Mediterranean salinity are the same, for they may have been causally related. The increasing Nile flow resulted from higher Sahara temperatures and stronger African monsoons as Northern summers began to occur closer to the perihelion point in Earth's orbit (Fig. 3). The effects of increasing Nile flow together with a large Heinrich event stopped Northern Hemisphere ice sheet growth, and triggered the start of the deglaciation of termination 2 in the proxy record for ice volume by eliminating the conveyor belt flow of that time and causing a completely zonal flow of the Gulf Stream across the northern North Atlantic. The duration of the collapse phase of the Canadian ice mass on this occasion is not known. However, the strong reduction of Mediterranean outflow inferred from the $>5{ }^{\circ} \mathrm{F}$ Sahara temperature until $125 \mathrm{ka}$ BP in Figure 3 may have been more than enough to ensure complete zonality and continued Eurasian deglaciation until all of that ice was gone. This would be consistent with the renewed pollen of temperate climate vegetation from lakes in northern Germany dated to 126 ka BP[27].

The rapidity of the Eurasian deglaciation during termination 2 can be explained by the storm paths associated with the complete zonality of the Gulf Stream, which implies a more zonal atmospheric flow across both North America and western Eurasia, at least in winter. Winter storms following the sharp temperature contrast of the oceanic polar front at the Gulf Stream edge would have entered cold Europe at the latitude of northern Spain (Fig. 8), too far south to contribute much snow to the Eurasian ice sheet. On the other hand, in summer when the unglaciated land was warm, the seas from the Canaries Current on the south to the seas bordering western Europe on the north remained very cool or cold. Therefore, the land-ocean temperature contrast would have steered summer storms under a jet stream northeastward from northwest Africa, dragging warm and dry air across Spain and France and onward over the Eurasian ice sheet. Rapid melting would have resulted. Melt waters discharged through the North Sea and Hudson Strait would have provided positive deglacial feedback by combining with the lower salinity and lower volume of the Mediterranean outflow to delay restoration of the conveyor belt flow, thus maintaining strong zonality until glacial ice was gone from Scandinavia, the warmth of a strong conveyor belt flow was restored, and most or all of the ice was gone from North America.

\subsection{Termination 1: transition from the last glacial extreme to today's interglacial}

The much slower recent deglaciation of termination 1 that ended in the Holocene in Scandinavia at 9 ka BP[41] and in Canada before 6 ka BP would have been driven by a less strong zonality of Gulf Stream flow that was associated with less-strong monsoons (Fig. 3). In termination 1 there was no close interaction between strong monsoons and a Heinrich event. The deglaciation began with Heinrich event $\mathrm{H} 1$ at about $19 \mathrm{ka} \mathrm{BP}$, close to the extreme of the last major glaciation with monsoon strength about equal to that of today. That event resulted in an associated sea level rise of about $20 \mathrm{~m}$. The initial sea level rise was therefore independent of any monsoon influence. However, the amount of sea level rise that was caused directly by the release of a Heinrich-event glacial ice from central Canada cannot always be separated from the rise caused by secondary effects. For example, the destablization of marine-based ice on eastern Canadian continental shelves by buoyancy effects may have extended the $\mathrm{H} 1$ event to $15 \mathrm{ka} \mathrm{BP}[42] .$. An abrupt $25 \mathrm{~m}$ sea level rise at about $14 \mathrm{ka} \mathrm{BP}$ has been attributed to breakup of unstable Antarctic ice masses. The following rise to a level of $-57 \mathrm{~m}$ at $11.4 \mathrm{ka} \mathrm{BP}$, the end of the Younger Dryas cold interval in Europe, occurred largely during Younger Dryas[36]. The cold climate of the Younger Dryas may have been caused by the combined zonality effect of strong monsoons, with Sahara temperatures above $4{ }^{\circ} \mathrm{F}$ (Fig. 3), and the zonality due to the Canadian melt water release that caused the reduction of conveyor belt flow. From 11.4 to $7.5 \mathrm{ka} \mathrm{BP}$, the added Sahara temperature remained largely between $4^{\circ} \mathrm{F}$ and $3{ }^{\circ} \mathrm{F}$ with a significant reduction of Mediterranean outflow that favored a stronger zonality that completed deglaciation of the Scandinavian part of the Eurasian ice sheet at $9 \mathrm{ka}$ BP. However, the zonality implied by the 
Holocene temperatures of the Sahara in Figure 3 remained well above present even for a time after the last significant Canadian ice disappeared about 6 ka BP. But again, the moderate zonality that favored the long termination 1 deglaciation implies an equally long interval of environmental stress for the hominid coastal population. At this point in the analysis, some of the available evidence was inconsistent with a known connecting monsoon across the Sahara. This problem was resolved with a report describing a humidity index for the Sahara.

\subsection{A humidity index and the connecting savannas on the Sahara}

\subsection{Timing and duration of the Holocene savanna}

Because of a cold Canaries Current, the establishment of a Holocene savanna connection between the coastal zone and the larger Africa did not follow in a straightforward way from stronger monsoons. The conflict occurs because quite strong monsoons maintain the aridity in northwestern Africa south of the coastal zone by keeping the Canaries Current strong and cold. The Canaries Current is cold because strong monsoons reduce the Mediterranean salinity, the volume rate of the outflow[30] and the conveyor belt flow, and consequently increase the zonality of the Gulf Stream and its

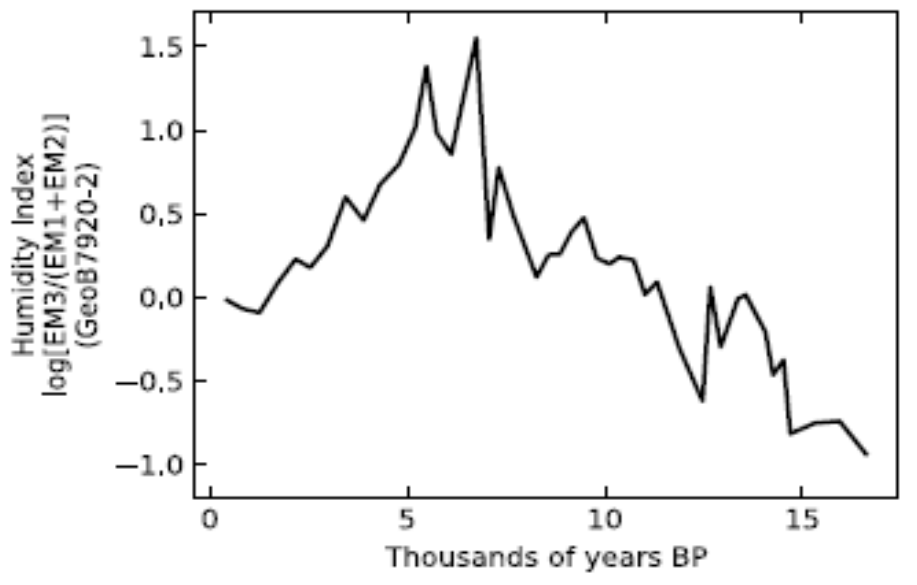

Figure 9: A Sahara humidity index from 16 ka BP to present. Modified from Figure 3 in reference [44]. The higher index values of 0.5 to 1.5 over the interval from $7.5 \mathrm{ka}$ BP to $4 \mathrm{ka}$ BP indicate the latest savanna that connected the coastal zone to the larger Africa, see text.

transport of a mixture of cold water from the Northern gyre into the Canaries Current. Furthermore, at least in the eastern part of the Sahara, the maximum northward extent of the Holocene monsoons is reported by Yan and Petit-Maire at $24^{\circ} \mathrm{N}$, the latitude of Aswan, at 8.5 ka BP[43], whereas a savanna connection requires a monsoon extent of at least $30^{\circ} \mathrm{N}$ in the western Sahara. The uncertainty of the timing of the last savanna raised by these facts can be resolved if the monsoon strength was still greater than today when the strong conveyor belt flow of interglacial time resumed, thus restoring a weak and warm Canaries Current. The savanna presence inferred from the high values of the Sahara humidity index reported by Tjallingii et al.[44] is consistent with this assumption.

The index was derived from the analysis of wind-blown sediments deposited over the last $120 \mathrm{ka}$ in deep sea core GeoB7920-2. This core was obtained off the coast of Mauritania at $20^{\circ} 45^{\prime} \mathrm{N}-18^{\circ} 35^{\prime} \mathrm{W}$, well north of today's monsoon zone. It is ideally located to receive dust eroded by trade winds from the Sahara. The proportions of sediment end members are related to erosion, changes in vegetation cover, and river runoff. Negative index peaks as low as -1.5 corelate with Heinrich events and Heinrich-like events of reduced thermohaline circulation in the marine core records. These events caused greater zonality with a stronger and colder Canaries Current and a colder and more arid climate to the east in the adjacent Sahara. Positive index values correlate with interstadials 
and interglacials when conveyor belt thermohaline circulation was strong and the Canaries Current was warm and weak. The Holocene part of this record is shown in Figure 9. Although the humidity index rose and remained slightly above present from $10 \mathrm{ka}$ BP until $8 \mathrm{ka} \mathrm{BP}$, the higher index values with peaks at a level up to 1.5 only occurred between $7.5 \mathrm{ka} \mathrm{BP}$ and $4 \mathrm{ka}$ BP. This $3.5 \mathrm{ka}$ interval of higher values suggests a humid savanna between those dates, at least in the western Sahara

One might have expected the savanna to have been established after the end of the Younger Dryas by 10 ka BP when warmer water is known to have extended northward to a location $600 \mathrm{~km}$ west of northern Ireland[45]. This implies a partial restoration of thermohaline circulation and conveyor belt flow. However, meltwater from the Scandinavian ice sheet that was discharged through the North Sea continued to reach the sea east of Greenland and would have maintained a higher zonality until the last Scandinavian ice was gone at 9 ka BP[41]. The monsoons and Nile flow apparently remained strong enough at that time to limit Mediterranean outflow and its salt, while the meltwater feedback from Canada continued to reinforce the effect of a reduced Mediterranean outflow. The humidity index implies that somewhat greater zonality of Gulf Stream flow was maintained until about 7.5 ka BP when the melt water volume from Canada became smaller, the monsoons became less strong as Sahara temperatures diminished (Fig. 3), and the salinity and rate of the Mediterranean outflow increased. These factors restored strong conveyor belt thermohaline circulation like today when the estimated Sahara temperature difference was about $3^{\circ} \mathrm{F}$. The humidity index then rose decisively to 1.5 above present, consistent with other evidence for a broad savanna[6]. The savanna remained until the humidity fell at $4 \mathrm{ka} B P$ as the monsoons continued to weaken, implying a savanna duration of slightly more than $3 \mathrm{ka}$. A similar interplay of the climate factors would be expected after termination 2, but with a shorter savanna duration of about $1.5 \mathrm{ka}$. This is consistent with a more rapid passage of summers through the perihelion point due to a larger eccentricity, and the Sahara temperature trend in Figure 3 after 123 ka BP.

\subsection{Sensitivity of the savanna humidity to a reduction of conveyor belt flow}

A reduction of conveyor belt flow like that occurring during the Little Ice Age[47] apparently caused a significant increase in Gulf Stream zonality and a reduction of Sahara humidity within the Holocene interval of the savanna connection. At about $6.3 \mathrm{ka}$ BP the humidity index in Figure 9 fell to 0.8 from 1.5 before rising again to another high point about $5.5 \mathrm{ka}$ BP. This drop occurred after all significant Northern meltwater discharges had ceased. It and three other subsequent smaller drops probably correlate with the internal bi-polar deep-ocean oscillation[47] that has a 1500 year periodicity and predicted minima in conveyor belt flow at $0.3,1.8,3.3,4.8$, and $6.3 \mathrm{ka} \mathrm{BP}$. The $0.3 \mathrm{ka} \mathrm{BP}$ minimum would have been lost in the loose sediment at the top of the deep-sea core[44]. That minimum corresponds to the cold Little Ice Age in Europe in late medieval times. The older minima back to $6.3 \mathrm{ka}$ BP would have been similar.

During the deep-ocean oscillation in medieval times the early medieval maximum of conveyor belt flow was probably comparable to the flow of today with the southward extent of winter sea ice near Spitsbergen at about $80^{\circ} \mathrm{N}$. The minimum flow during the Little Ice Age about $1695 \mathrm{AD}$ allowed sea ice to advance southward to $60^{\circ} \mathrm{N}$, almost to northern Scotland[48]. The amplitude of this change in terms of Gulf Stream zonality and Canaries Current temperature would have had a small effect on the already arid Sahara in the absence of the savanna, but with the savanna present, the implied reduction of precipitation at $6.3 \mathrm{ka}$ BP made a significant change in the humidity index for a few hundred years and probably also in the character of the savanna. A somewhat stronger reduction of conveyor belt flow would likely have prevented the presence of the savanna.

\subsection{A paleo sea level rule for the formation of connecting savannas}

The amount of Northern Hemisphere deglaciation is reflected in the change in the oxygen isotope ratio proxy for world ice volume and sea level variation relative to today's ice-free Northern continents and today's world high sea level. The amount of Northern deglaciation that can enable the occurrence of savannas on the Sahara can be approximately estimated in terms of world sea level over the last 120 ka by using the Sahara humidity index[44]. The last of the Eurasian ice disappeared in Scandinavia at 9 ka BP[41] with world sea level at about $25 \mathrm{~m}$ and Sahara temperatures at $3.6^{\circ} \mathrm{F}$. But the humidity index did not indicate a savanna until about $7.5 \mathrm{ka}$ BP 
when world sea level due to residual glacial ice was still below present at about $-15 \mathrm{~m}$, see Figure 2 of reference[36]. The Sahara temperature was then $3.0^{\circ} \mathrm{F}$. Therefore, it appears that between 9 and $7.5 \mathrm{ka} \mathrm{BP}$ monsoons were still too strong and the Canaries Current still too cold to allow enough monsoon rainfall for savanna development. But about 7.5 ka BP the humidity index entered the upper range of +0.25 to +1.50 in the Holocene record (Fig. 9), implying savanna formation. In the last $120 \mathrm{ka}$, the index was in this upper range narrowly at $83 \mathrm{ka} \mathrm{BP}$ and generously at $105 \mathrm{ka} \mathrm{BP[44],} \mathrm{implying} \mathrm{savannas} \mathrm{also} \mathrm{near} \mathrm{those} \mathrm{times.} \mathrm{World} \mathrm{sea} \mathrm{levels}$ then, as measured by uplifted reefs on Barbados, were found to have been $-14 \mathrm{~m}$ and $-11 \mathrm{~m}$ respectively[49]. These data suggest the rule used to obtain the results of Figure 3 for the acceptance of other ages when savannas occurred: The world sea level, as judged from the dated oxygen isotope ratio proxy for sea level and ice volume changes[49], must have been higher than $-15 \mathrm{~m}$, thus implying a complete Eurasian deglaciation with a warmer and weaker Canaries Current at a time when monsoons were strong enough, but not too strong, to establish a savanna.

\subsection{Results and discussion}

\subsection{Perihelion summer ages with and without savanna connections}

The Sahara temperatures at perihelion points in Figure 10 are proxy for African monsoon strength. They are all well above present because Earth is now near a distant point in the orbit during Northern summers and monsoons are relatively weak. The lower Sahara temperatures near today and near $400 \mathrm{ka}$ and $800 \mathrm{ka}$ BP are due to relatively low orbital eccentricity with Earth more distant from the sun during perihelion summers. The absence of inferred complete Eurasian deglaciation near the circled points suggests a strong and cold Canaries Current, and a condition of intermediate zonality and regrowth of glacial ice, with no mild climate like that of today in the coastal zone following an extremely arid interval during deglaciation. The black time-line line below is interrupted by red dots that indicate ages of probable savanna connections to the larger Africa, and the longer intervals between savannas. The plotted values and differences are also shown in Table 1.

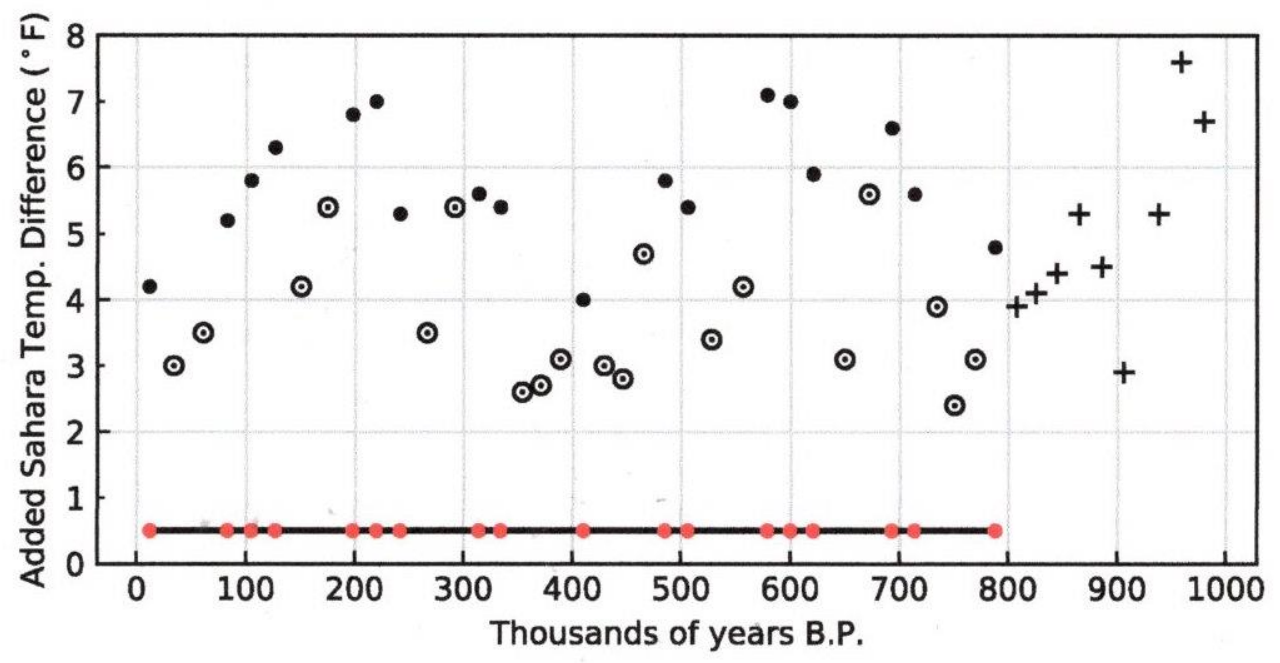

Figure 10: Calculated maximum summer temperature above present at $25 \mathrm{~N}$ on the Sahara when summer occurred at the orbital perihelion point. The occasions when no savanna resulted are designated by the circled points according to the rule in section 8.3. Ages are from Berger[15]. Crosses are points without a dated ice volume proxy in reference [46].

\subsection{Summary: the coastal zone hypothesis of hominid evolution}

Much of the evolution of the hominid family of man occurred in small steps under selective pressures of both warm and cold environments in the cyclically isolated Moroccan coastal zone. The injection of each resulting new sub species or species of hominids into the larger Africa occurred during 1-3 ka intervals when the Sahara Desert 
was converted into a broad savanna by somewhat stronger West African monsoons. Stronger monsoons were generated by atmospheric pressure differences larger than today, caused by increased heating of northern Africa relative to the ocean area to the southwest. But savannas could only occur in the glacial climate cycle after the Eurasian deglaciations were completed, thus ending the extreme aridity of the coastal zone with monsoon strength still somewhat greater than today. The separation between brief pluvial intervals ranged from $\sim 20 \mathrm{ka}$ to $\sim 76$ ka during the Pleistocene because deglaciation of the Eurasian ice sheet was sometimes incomplete when ice sheet growth resumed. Similar variations probably occurred through much of the Pliocene. During the brief times of savanna connections, the genetically altered populations of the coastal zone would increase their numbers, extend their range into the larger Africa, and mingle with the then currently un-modified population south of the Sahara.

The precise way by which speciation occurred is a subject of speculation. An isolation interval of only 20 ka may be too short to evolve the unique characteristics of a new species, and cross breeding with the larger unmodified population in the greater Africa and the coastal zone after the savanna connection was made could have diluted the genetic changes and altered the combined larger population only slightly, with resulting slow evolution. Even the longer intervals of $\sim 76 \mathrm{ka}$ might not have been an adequate length of time. But a population having relatively unchanged new genetic characteristics would likely have remained in the coastal zone during the brief times of savanna connections. If so, the accumulation of new characteristics would have continued there through multiple cycles until reproductive isolation enabled the preservation of a new species in the fossil record south of the Sahara. The cyclic isolation of earlier hominids in the coastal zone may have started with savanna-like connections soon after 4.2 Ma BP near the beginning of the Pliocene when the Mediterranean Sea was reconnected to the Atlantic[2]. Soon after 3 Ma BP the evolution of the isolated hominids would probably have been accelerated when longer intervals of environmental stress were brought on by the onset of large-scale glaciations. Without this four million year-stream of evolutionary pulses from the coastal zone, the earliest species of Homo precursors might well have remained comfortably adapted to the more equable environments south of the Sahara, and never have evolved to the Homo sapiens level.

Table 1: Lengths of isolation intervals and ages and delta increases of Sahara temperature when summers occur at perihelion, as plotted in Figure 10. The savannas occur following the perihelion maximum of insolation, after each isolation interval in column 2.

\begin{tabular}{ccccccc}
$\begin{array}{c}\text { Age } \\
(\mathrm{ka})\end{array}$ & $\begin{array}{c}\text { isolation } \\
\text { interval }(\mathrm{ka})\end{array}$ & $\begin{array}{c}\text { delta } \\
\left({ }^{\circ} \mathrm{F}\right)\end{array}$ & $\begin{array}{c}\text { Age } \\
(\mathrm{ka})\end{array}$ & $\begin{array}{c}\text { delta } \\
\left({ }^{\circ} \mathrm{F}\right)\end{array}$ & $\begin{array}{c}\text { Age } \\
(\mathrm{ka})\end{array}$ & $\begin{array}{c}\text { delta } \\
\left({ }^{\circ} \mathrm{F}\right)\end{array}$ \\
\hline 12 & 71 & 4.2 & 34 & 3.0 & 808 & 3.9 \\
83 & 22 & 5.2 & 61 & 3.5 & 826 & 4.1 \\
105 & 22 & 5.8 & 151 & 4.2 & 845 & 4.4 \\
127 & 71 & 6.3 & 175 & 5.4 & 865 & 5.3 \\
198 & 22 & 6.8 & 267 & 3.5 & 886 & 4.5 \\
220 & 22 & 7.0 & 292 & 5.3 & 906 & 2.9 \\
242 & 72 & 5.3 & 354 & 2.6 & 938 & 5.3 \\
314 & 20 & 5.6 & 371 & 2.7 & 959 & 7.6 \\
334 & 76 & 5.4 & 389 & 3.1 & 980 & 6.7 \\
410 & 75 & 4.0 & 429 & 3.0 & & \\
485 & 21 & 5.8 & 446 & 2.8 & & \\
506 & 73 & 5.4 & 465 & 4.7 & & \\
579 & 21 & 7.1 & 528 & 3.4 & & \\
600 & 21 & 7.0 & 557 & 4.2 & & \\
621 & 72 & 5.9 & 650 & 3.1 & & \\
693 & 21 & 6.6 & 672 & 5.6 & & \\
714 & 74 & 5.6 & 735 & 3.9 & & \\
788 & $?$ & 4.8 & 751 & 2.4 & & \\
& & & 770 & 3.1 & &
\end{tabular}


was converted into a broad savanna by somewhat stronger West African monsoons. Stronger monsoons were generated by atmospheric pressure differences larger than today, caused by increased heating of northern Africa relative to the ocean area to the southwest. But savannas could only occur in the glacial climate cycle after the Eurasian deglaciations were completed, thus ending the extreme aridity of the coastal zone with monsoon strength still somewhat greater than today.

The separation between brief pluvial intervals ranged from $\sim 20 \mathrm{ka}$ to $\sim 76 \mathrm{ka}$ during the Pleistocene because deglaciation of the Eurasian ice sheet was sometimes incomplete when ice sheet growth resumed. Similar variations probably occurred through much of the Pliocene. During the brief times of savanna connections, the

genetically altered populations of the coastal zone would increase their numbers, extend their range into the larger Africa, and mingle with the then currently un-modified population south of the Sahara. The precise way by which speciation occurred is a subject of speculation. An isolation interval of only $\sim 20$ ka may be too short

to evolve the unique characteristics of a new species, and cross breeding with the larger unmodified population in the greater Africa and the coastal zone after the savanna connection was made could have diluted the genetic changes and altered the combined larger population only slightly, with resulting slow evolution. Even the longer intervals of $\sim 76 \mathrm{ka}$ might not have been an adequate length of time. But a population having relatively unchanged new genetic characteristics would likely have remained in the coastal zone during the brief times of savanna connections. If so, the accumulation of new characteristics would have continued there through multiple cycles until reproductive isolation enabled the preservation of a new species in the fossil record south of the Sahara. The cyclic isolation of earlier hominids in the coastal zone may have started with savanna-like connections soon after 4.2 Ma BP near the beginning of the Pliocene when the Mediterranean Sea was reconnected to the Atlantic[2]. Soon after $3 \mathrm{Ma}$ BP the evolution of the isolated hominids would probably have been accelerated when longer intervals of environmental stress were brought on by the onset of large-scale glaciations. Without this four million year-stream of evolutionary pulses from the coastal zone, the earliest species of Homo precursors might well have remained comfortably adapted to the more equable environments south of the Sahara, and never have evolved to the Homo sapiens level.

\subsection{Concluding remarks}

The concept of cyclic evolution in the Moroccan coastal zone, based on orbital effects, embodies a repetitive refuge in which hominid evolution occurred over most of Plio-Pleistocene time. It is an especially attractive explanation for the Homo family and its predecessors who seem to have lived on savannas like the dry environment of the coastal zone. The environmental climate factors varied broadly and repeatedly within each climate cycle because of Heinrich-like events that usually originated in Canada and because of orbital effects on African monsoons. Permanent hominid adaptations to any one special food or any other way of life were not likely.

The cyclic evolution concept also offers answers to the questions posed in the introduction of this paper: (1) Why did hominids evolve in Africa and not elsewhere in the world? Only in the Moroccan coastal zone would have been found the repetitive conditions of a small and confined population in highly stressful environments during the last $4 \mathrm{Ma}$. In a dry and sometimes quite arid environment, competition between tribal elements within the hominid population for scarce resources may have been a guiding factor during the cyclic evolution. If so, only in the Moroccan coastal zone would the critical selective factors of physical ability, mental ingenuity, and social cohesion have been applied repeatedly to small hominid populations. Each successive climate cycle therefore offered the possibility of developing those traits to a greater extent. (2) Why did apes and other primates that might have shared the coastal zone at the beginning of each isolation fail to evolve like the hominids? In that isolated environment, starvation would have been an ever-present threat. Therefore, any competitors that could be successfully hunted would have been viewed as prey, and may have been eliminated early in each cycle after the isolation began. 


\section{Acknowledgments}

In addition to his other contributions to the paper, co-author André Berger kindly supplied copies of his tabulated values of caloric summer insolation over the last million years. Ryan Skinner assisted with the illustrations. Wendy Johnson assisted in formatting.

\section{References}

1. deMenocal, P. B. (2004). African climate change and faunal evolution during the Pliocene-Pleistocene. Earth and Planetary Science Letters, 220, 3-24.

2. Hsu, K. J., Montadert, L., Bernoulli, D., Cita, M. B., Erickson, A., Garrison, R. E., Kidd, R. B., Melieres, F., Müller, C., \& Wright, R. (1977). History of the Mediterranean salinity crisis. Nature, 267, 399-403.

3. Raynal, J. P., Sbihi Alaoui, F. Z., Geraads, D., Magoga, L., \& Mohib, A. (2002). The earliest occupation of NorthAfrica: the Moroccan perspective. Quaternary international, 75(1), 65-75.

4. Bobe, R., Behrensmeyer, K., \& Chapman, R. (2002). Faunal change, environmental variability and late Pliocene hominin evolution. Journal of human evolution, 42(1), 475-497.

5. Stewart, J. B., \& Stringer, C. B. (2012). Human evolution out of Africa: the role of refugia and climate. Science, 335, 1317-1321.

6. Rossignol-Strick, M. (1983). African monsoons, an immediate climate response to orbital insolation. Nature, 304, 46-49.

7. Rossignol-Strick, M. (1985). Mediterranean sapropels, an immediate response of the African monsoon to variation of insolation. Palaeogeography, palaeoclimatology, palaeoecology, 49, 237-263.

8. Rossignol-Strick, M., Paterne, M. M., Bassinot, F., Emeis, K. C., \& De Lange, G. J. (1998). An unusual midPleistocene monsoon period over Africa and Asia. Nature, 392, 269-272.

9. Street-Perrott, F.A., \& R.A. Perrott. (1993). Holocene vegetation, lake levels, and climate of Africa. In: Wright, H. E., et al. (Eds.), Global climates since the last glacial maximum (pp. 318-356). Minneapolis, MN: University of Minnesota Press.

10. Spoor, F. P., Neubauer, S., Steizer, S., Scott, N., Kwekason, A., \& Dean, P. (2015). Reconstructed homo habilis type $\mathrm{OH} 7$ suggests deep-rooted species diversity in early homo. Nature, 519, 83-86.

11. Hublin, J. J., Ben-Ncer, A., Bailey, S. E., Freidline, S. E., Newbauer, S., Skinner, M. M., Bergmann, I., Le Cabec, A., Benazzi, S., Harvati, K. \& Gunz, P. (2017). Nature, 546, 289-292.

12. Broecker, W.S. (1991). The great ocean conveyor. Oceanography. 4, 79-90.

(2018). In Encyclopedia

Britannica.

Retrieved from https://www.britannica.com/science/harmattan

14. Johnson, R. G. (2018). Initiation of the last ice age in Canada by a cascade of oceanic salinity increases. Journal of advances in natural science, 3(1), 237-252.

15. Berger, A. L. (1978). Long term variations of caloric summer insolation resulting from Earth's orbital elements. Quaternary research, 9(2), p. 237. (Tabulated results and eccentricity values supplied by personal communication.)

16. Bartholomew, A. L. (1950). The advanced atlas of modern geography (p. 78). London: Meiklejohn and Son, Ltd. 
17. Vernekar A. D. (1972). Long-period global variations of incoming solar radiation. In: Long-period global variations of incoming solar radiation. Meteorological monograph. 12. Boston, MA: American Meteorological Society.

18. Ruddiman, F. F., Maclntyre, J., Niebler-Hunt, \& Durazzi, J. T. (1980). Oceanic evidence for the mechanism of rapid Northern Hemisphere glaciation. Quaternary research, 17, 135-147.

19. Ruddiman, F. F., Molfino, B., Esmay, A., \& Pokras, E. (1980). Evidence bearing on the mechanism of rapid deglaciation. Climate change, 3, 65-87.

20. Heinrich, H. (1988). Origin and consequences of cyclic ice rafting in the northeast North Atlantic Ocean during the past 130,000 years. Quaternary research, 29, 143-152.

21. Stravers, J. A., Miller, G. H., \& Kaufman, D. S. (1988). Late glacial ice margins and deglacial chronology for southeastern Baffin Island and Hudson Strait, eastern Canadian Arctic. Canadian journal of earth science, 29, 1000-1007.

22. Blake, W. (1966). End moraines and deglaciation chronology in northern Canada, with special reference to southern Baffin Island. Geological Survey of Canada. Paper. 66-76.

23. Johnson, R. G., \& Lauritzen, S. E. (1966). Hudson Bay-Hudson Strait Jokulhlaups and Heinrich events: a hypothesis. Palaeogeography, palaeoclimatology, palaeoecology, 117, 123-137.

24. Bond, G. W., Broecker, W., Johnsen, S., McManus, J., Labeyrie, L., Jouzel, J., \& Bonani, G. (1993).

a. Correlation between climate records from North Atlantic sediments and Greenland ice. Nature, 365, 143147.

25. Gallup, C. D., Edwards, R. L., \& Johnson, R. G. (1994). The timing of high sea levels over the past 200,000 years. Science, $263,796-800$.

26. Ruddiman, W. F., \& McIntyre, A. (1994). Oceanic mechanisms for amplification of the 23,000-year ice-volume cycle. Science, 212, 617-627.

27. Field, M. H., Huntley, B., \& Müller, H. (1994). Eemian climate fluctuations observed in a European pollen record. Nature, 371, 779-783.

28. Kallel, N., Duplessy, J. C., Labeyrie, L., Fontugne, M., Paterne, M., \& Montacer, M. (2000). Mediterranean pluvial periods and sapropel formation over the last 200,000 years. Palaeogeography, palaeoclimatology, paleoecology, 157, 45-58.

29. Muerdter, D. R. (1984). Low-salinity surface water incursions across the Strait of Sicily during Late Quaternary sapropel intervals. Marine geology, 58, 401-414.

30. Bryden, H. L., \& Kinder, T. H. (1991). Steady two-layer exchange through the Strait of Gibraltar. Deep-sea research, 38 Suppl. 1., 5445-5463.

31. Reid, L. L. (1979). On the contribution of the Mediterranean Sea outflow to the Norwegian-Greenland Sea. Deep-sea research, 26, 1199-1223.

32. Greatbatch, R. J., \& Xu, J. (1993). On the transport of volume and heat through sections across the North Atlantic: Climatology and the pentads 1955-1959, 1970-1974. Journal of geophysical research, 98, 1012510143.

33. Worthington, L. V. (1976). On the North Atlantic Circulation, Johns Hopkins oceanographic studies No. 6 (p. 7). Baltimore, MD: Johns Hopkins University Press. 
34. Arkhipov, S. A., Ehlers, J., Johnson, R. G., \& Wright, H. E. (1995). Glacial drainage toward the Mediterranean during Middle and Late Pleistocene. Boreas, 24, 196-206.

35. Johnson, R. G. (2001). Last interglacial seastands on Barbados and an early anomalous deglaciation timed by differential uplift. Journal of geophysical research, 106 (C6), 11543-11551.

36. Fairbanks, R. G. (1990). The age and origin of the "Younger Dryas climate event" in Greenland ice cores. Paleoceanography, 5, 937-948.

37. Esat, T. M., McCulloch, M. T., Chappell, J., Pillans, B., \& Omura, A. (1999). Rapid fluctuations in sea level recorded at Huon Peninsula during the penultimate deglaciation. Science, 238, 197-201.

38. Muhs, D. R., Pandolfi, K. R., Simmons, K. R., \& Schumann, R. R. (2012). Sea level history of past interglacial periods from Uranium-series dating of corals, Curacao, Leeward Antilles islands. Quaternary research, 78, 157-168.

39. Mesolella, K. J., Mathews, R. K., Broecker, W. S., \& Thurber, D. L. (1969). The astronomical theory of climate change: Barbados data. Journal of geology, 77, 250-274.

40. Thunell, R. C., \& Williams, D. F. (1982). Paleoceanographic events associated with termination II in the eastern Mediterranaean. Oceanologica acta, 5, 229-233.

41. Lambeck, K., Yokoyama, Y., Johnston, P., \& Purcell, A. (2000). Global ice volumes at the Last Glacial Maximum and early Late Glacial. Earth and planetary science letters, 181, 513-527.

42. Bard, E., Rostok, T., Turon, J. L., \& Gendreau, S. (2000). Hydrological impact of Heinrich events in the subtropical northeast Atlantic. Science, 289, 1321-1324.

43. Yan, Z., \& Petit-Maire, N. (2000). The last $140 \mathrm{ka}$ in the Afro-Asian arid/semiarid transitional zone. Palaeogeography, palaeoclimatology, paleoecology, 110, 217-233.

44. Tjallingii, R., Claussen, M., Stuut, J. W., Fohlmeister, J., Alexandra, J. J., Bickert, T., Lamy, F., \& Ruhl, U. (2008). Coherent high- and low-latitude control of the northwest African hydrological balance. Nature geoscience, 1, 670-675.

45. Ruddiman, W. F., \& Mclntyre, A. (1973). Time-transgressive deglacial retreat of polar waters from the North Atlantic. Quaternary research, 3, 117-130.

46. Johnson, R. G. (1982). Brunhes-Matuyama magnetic reversal dated at $790,000 \mathrm{yr}$ by marine-astronomical correlations. Quaternary research. 17, 135-147.

47. Johnson, R. G. (2015). Did a bi-polar multi-level oceanic oscillation cause the Little Ice Age and other high latitude climate extremes? Journal of advances in natural sciences, 3(1), 228-236.

48. Lamb, H. H. (1995). Climate, History and the Modern World (2nd ed., p. 60). Routledge, NY: Johns Hopkins University Press.

49. Bender, M. L., Fairbanks, R. G., Taylor, F. W., Mathews, R. K., Goddard, J. G., \& Broecker, W. S. (1979). Uraniumseries dating of the Pleistocene reef tracts of Barbados, West Indies. GSA bulletin, 90, 577-594. 